\title{
K teorii aktivního vzdělávacího obsahu $\checkmark$ transdidaktickém pojetí
}

\author{
Jan Slavík ${ }^{1}$, Tomáš Janík ${ }^{2}$, Jiří Kohout ${ }^{1}$, \\ Tereza Češková ${ }^{2}$, Pavel Mentlík ${ }^{1}$, Petr Najvar ${ }^{2}$ \\ ${ }^{1}$ Západočeská univerzita v Plzni, Fakulta pedagogická \\ ${ }^{2}$ Masarykova univerzita, Pedagogická fakulta
}

\begin{abstract}
Abstrakt: Teoretická studie vychází z Fishermanova pojetí aktivního obsahu jako činitele kognitivní změny a Kvaszova teorému, že kognitivní změny na úrovni historické kulturní epistemologie a kognitivní změny na úrovni osobní epistemologie žáků lze vysvětlovat shodnou typologií. Studie hledá objasnění této shody prostřednictvím konstruktů „intencionalita“, „obsahová transformace“ a ,instrumentalizace zkušenosti“. Edukační působnost aktivního obsahu mezi kulturní a osobní úrovní je vysvětlována s oporou v pojmu mem, který reprezentuje jak tvorbu aktivního obsahu v kulturní historii, tak distribuci aktivního obsahu ve společnosti a jeho vliv na jednotlivce. Nástrojem pro replikaci memů ve vzdělávacím prostředí jsou učební úlohy, jejichž vliv na kognitivní změny u žáků je podmíněný sémantickou a logickou strukturací kognitivních schémat. Na tomto explanačním základě je ve studii z transdidaktického hlediska interpretována Kvaszova typologie kognitivních změn vycházející z analýzy vědeckých revolucí v kulturní historii.
\end{abstract}

Klíčová slova: aktivní obsah, vzdělávací obsah, obsahová transformace, intencionalita, mem, schéma, transdisciplinární didaktika

\section{On the Theory of Active Educational Content in a Transdisciplinary Perspective}

\begin{abstract}
This theoretical study builds on Fisherman's view of active content as an agent of cognitive change and on Kvasz's theorem that cognitive changes on the level of historical cultural epistemology and cognitive changes on the level of student's personal epistemology can be explain through the same typology. The paper looks for the clarification of this agreement through concepts like "intentionality", "content transformation" and the "instrumentalization of experience". The educational potential of active content between the cultural and the personal level is explained with reference to the concept of "meme", which represents the creation of active content in cultural history as well as the distribution of active content within society and its influence upon an individual. The tools for meme replication in educational environment are learning tasks; they generate cognitive changes in students insomuch as they have sound semantic and logical structure of cognitive schemata. Upon this explanatory basis authors interpret Kvasz's typology of cognitive changes that stems from the analysis of scientific revolutions in the cultural history.
\end{abstract}

Keywords: active content, educational content, content transformation, intentionality, meme, schema, transdisciplinary didactic 
Vzdělávací obsah patři ke kličovým pojmům pedagogické teorie ve vztahu k vzdělávací praxi, protože je ústřední kategorií jak pro didaktiku, tak pro teorii kurikula, které mají z pedagogických věd relativně nejbliže $k$ vzdělávací práci učitelů ve výuce právě proto, že se věnují vzdělávacímu obsahu. V kurikulu je obsah konkretizovaný ve vzdělávacích oborech, značně rozrůzněných i rozmanitě svázaných s obory kultury. Teorie vzdělávacího obsahu proto musí být transdisciplinární, dostatečně zobecňující i dostatečně operacionální, aby jejich dynamiku a variabilitu zastřešila. Východiskem pro takovou teorii je společný cíl všech vzdělávacích oborů: přispívat ke kulturnímu rozvoji žákovské zkušenosti. ${ }^{1}$ Lidská zkušenost z principu nemůže být bezobsažná, a má-li se rozvíjet, musí být re-kreativní. ${ }^{2}$ Re-kreativní působnost obsahu na proměny zkušenosti byla Fishermanem charakterizována termínem aktivní obsah. Aktivní obsah způsobuje kauzální změny mentálních operací (Fisherman, 2012, s. 163) obecně nazývané kognitivní změny. Na tomto explanačním základě se didaktice nabízejí př́ležitosti k syntéze psychodidaktických konstruktů orientovaných na žákovské učení s ontodidaktickými konstrukty zaměřenými na kulturní kontext vzdělávání.

Naše stat' má být příspěvkem $\mathrm{k}$ teorii vzdělávacího obsahu $\mathrm{v}$ transdisciplinárním pojetí. Transdisciplinární didaktika (Slavík et al., 2017a) usiluje o takové generalizace např́íc vzdělávacími obory, které nevedou k separaci od oborových didaktik a k „vyprazdňování obsahu“ z teorie a empirického výzkumu výuky (Janík et al., 2018). Gordickým uzlem vyprazdňování obsahu jsou právě kognitivní změny.

Kvasz (2020) kriticky konstatuje, že tradičními př́stupy kognitivní psychologie se nedaří rozlišovat typy kognitivních změn, které by poskytly př́ležitost „vidět kognitivní jevy $v$ jejich čistotě“. Kognitivní změny jsou totiž podmíněné historickým rozvojem kulturních instrumentů poznávání, a proto se ukazují jen v dlouhém časovém horizontu vývoje oborů (Kvasz, 2015, 2020). Tato teze předpokládá, že kognitivní změny na úrovni historického kulturního rozvoje a kognitivní změny na úrovni sociokulturního učení subjektů (žáků) lze vysvětlovat shodnou typologií.

Kvasz (2001) v diskusi s Rybárem doložil, že typologie kognitivních změn odvozované z empirických výzkumů ontogeneze nedokážou objasnit celý rozsah a specifické kvality těchto změn pozorovaných $v$ historii kulturního vývoje oborů. Ani v této diskusi, ani ve svých didakticky zaměřených textech (Kvasz, 2016, 2020) však nezavedl systém teoretických konstruktů pro výklad vztahů mezi epistemickými operacemi s aktivním obsahem utvářejícím subjektivní zkušenost a sémanticko-logickými strukturami, které tuto zkušenost začleňují do sociokulturně sdíleného kontextu $\mathrm{v}$ oborech. Teze o genetické paralele mezi ontogenetickou a kulturně-historickou rovinou kognitivních změn tím naráží na mezeru v koherentním teoretickém vysvětlení.

1 Pro pojmenování subjektivního potenciálu intencionálních aktivit získaného učením existuje mnoho rozmanitých termínů: znalost, dovednost, schopnost, dispozice, gramotnost, kompetence... $\checkmark$ tomto textu uživáme termín zkušenost jako jejich všeobecný ekvivalent. Opíráme se o pragmatickou tradici zkušenostního učení: zkušenost je kognitivní zhodnocení interakce s kulturním a prírodním prostředím pro budoucí kulturní praktiky (srov. Dewey, 1938, s. 42; Kolb, 1984, s. 35; Slavík et al., 2017a, s. 142-143).

2 Re-kreace zkušenosti zahrnuje jak produktivní-inovativní, tak reproduktivní charakter procesu. 
V následujícím textu usilujeme o překlenutí této mezery ve výkladu prostřednictvím transdidaktické teorie obsahové transformace založené na filozofickém konceptu intencionality a s oporou ve Fishermanově (2012) pojetí aktivního obsahu opřené o Dawkinsův termín mem jako replikační jednotku kulturní transmise. Cílem je formulovat operacionální teoretické konstrukty, funkční pro reflektivní praxi výuky a pro výzkum kvality výuky. Nynější text navazuje na řadu předcházejících statí a monografií, ${ }^{3}$ avšak pro zachování srozumitelnosti se nemůže spoléhat jenom na odkazy k nim. Proto některé již dřive elaborované poznatky zde předkládá znovu v aktuálním kontextu.

\section{Analytická východiska}

V této kapitole formulujeme vstupní teze, které mají tvořit zdůvodněnou a logicky ucelenou myšlenkovou strukturu pro další speciálnější výklad. Axiomem, který již dále nezdưvodňujeme, je normativní předpoklad, že jednotícím cílem vzdělávacích oborů je kulturně obohacovat a rozvíjet žákovskou zkušenost prostřednictvím kognitivních změn.

\subsection{Aktivní obsah}

Slovem obsah říkáme, že něco existuje v něčem nebo prostřednictvím něčeho. Pojem obsah tím poukazuje na vše, co považujeme za významově určitelné, aniž to přímo určujeme; např. obsah zkušenosti, obsah pojmu, obsah obrazu, znalost obsahu. ${ }^{4}$ Označením obsah též vystihujeme úplnost, kupř. obsahem zkušenosti se míní celá zkušenost, nikoliv jen její část. Je-li nějaká část obsahu jmenovitě určena interpretací, chápeme ji jako strukturní jednotku nadřazeného celku (kontextu) pod názvy pojem, význam, koncept aj.

Obsah, jímž se zkušenost v kulturním kontextu uchovává, ji zároveň přetváríi. Obsah má tedy v kultuře podvojnou re-kreativní funkci: reproduktivní - transmisivní a produktivní - inovativní. ${ }^{5}$ Fisherman (2012) tuto podvojnost charakterizuje termínem aktivní obsah (active content): aktivní obsah zapřičiňuje kognitivní změnu (inovaci) i trvání (reprodukci) zkušenosti u jedinců a prostřednictvím jejich interakcí též v celém kulturním poli. Vzdělávací obsah je aktivní obsah zaměřený na

3 Koncepce transdidaktiky je postupně rozvíjena v monografiích z let 2013 (Slavík et al. či Janík et al.), 2017 (Slavík et al., 2017a) a v soustavné řadě časopiseckých studií od roku 2005 (Slavík \& Janík, 2005, 2006, 2012; Janík \& Slavík, 2009).

4 Pojem obsah svým pojetím koresponduje s Aristotelovým pojetím ontologické kategorie látka. Látka je kategorií vystihující princip „neurčené určitelnosti“: je předpokladem každého určení „něčeho“, ale sama zůstává neurčena (srov. Aristotelés, cca 350 př. n. l./2008, s. 168 aj.). Pojem obsah ve stejném smyslu reprezentuje „všezahrnující totalitu možností “ zahrnující všechny potenciální části celků ve „struktuře přináležitosti“ (srov. Barbaras, 2005, s. 96; Šíp, 2016, s. 22).

5 Vztah kreace a re-kreace není téma nikterak nové, kupř. v dětské hře se mu věnoval již Lee (1920). 
12 efektivitu kulturní transmise a podvojná reproduktivně-produktivní funkce je pro něj charakteristická.

Aktivní obsah je Fishermanem (2012, s. 165-166) charakterizován s oporou o dva stěžejní konstrukty sociokulturního učení L. S. Vygotského (1976): internalizaci sociálně zprostředkovaných interakcí a zónu nejbližšího vývoje. Podmínkou re-kreace zkušenosti je tedy zvnitřňování vnějších sociokulturních interakcí v zóně nejbližšího vývoje, tj. na takové úrovni náročnosti, na níž lze individuální kognitivní růst stimulovat sociokulturním učením (podrobněji Štech, 2013). Tehdy dochází ke kognitivním změnám: zkušenost se vlivem aktivního obsahu re-kreativně mění.

Termín kognitivní změna je založen na třech základních podmínkách působnosti aktivního obsahu, které považujeme za nutné k Fishermanově koncepci dodat: identita, přirůstek, rekonstrukce. Podle první podmínky musí být změna rozpoznatelná na bázi obsahové identity (vědět lépe o „tomtéž“). Druhá podmínka poukazuje na přínosnost změny: přírůstek vědění (vědět více...). Třetí podmínka vypovídá o tom, že kognitivní změny vedou k novému uspořádání zkušenosti (vědět jinak...). Takto podmíněný typ změn nazýváme relační změnou.

Bez termínu relační změna nelze operacionálně vysvětlit kauzální pưsobnost sémanticko-logické struktury aktivního obsahu na mentální operace a změny zkušenosti. Relační změny jsou totiž přiznačné tím, že proměna dílčích prvků struktury obsahu způsobuje více či méně rozsáhlé re-konstrukce v celé síti významových a logických souvislostí uspořádaných předcházejícími operacemi (Slavík et al., 2017b, s. 22). ${ }^{6}$ Relační změny jsou změny v síti rozlišení a vzájemných poukazů mezi částmi a celky (typicky při osvojování nového pojmu nebo nové dovednosti).

\subsection{Memy a jejich replikace v kulturním kontextu na bázi schémat}

Pro vysvětlení podvojné funkce aktivního obsahu se předpokládá supervenience ${ }^{7}$ mozku a zkušenosti, resp. mysli - re-kreativní změny zkušenosti jsou v mozku kotveny ve stavech neuronálních událostí, ale závisejí na intersubjektivně sdíleném

6 Pro empirické zkoumání a komplexní vysvětlování procesů relačních změn v učebním prostředí je zapotřebí analyzovat hloubkovou strukturu výuky (Janík et al., 2013, s. 228-232; Slavík et al., 2017 a, s. 338-348). Hloubková struktura výuky modeluje vzájemné vztahy mezi třemi úrovněmi dynamické existence obsahu: 1) očekávaným stavem mentálních schémat žáků (cílová-kompetenční, resp. znalostní úroveň), 2) stavem sémanticko-logických struktur v př́slušném kulturním oboru transformovaným pro zónu nejbližšího vývoje (konceptová úroveň), 3) funkčními charakteristikami učebních úloh, které konstituují učební prostředí a podmiňují re-kreativní změny žákovské zkušenosti (tematizační úroveň).

7 Supervenience je pojmenování pro vztah ontologické závislosti mezi dvěma genericky odlišnými soubory vlastností (zde mezi vlastnostmi mozku a vlastnostmi obsahu zkušenosti) podmíněný tím, že každá změna vlastností objektu patřícího do prvního souboru (supervenujících vlastností) zahrnuje změnu vlastností a zároveň je zpưsobena změnou vlastností patřících do druhého souboru subvencujících vlastností (Slavík et al., 2013, s. 53-57; Britannica, 2017). Např́klad správné užití pojmu „červený“ je podmíněno pozorováním červené věci a při změně její barvy se má změnit i přiřazený pojem. A správné užití pojmu „barevný“ je analogickým způsobem podmíněno podřazenými pojmy „červený“, „žlutý“, „modrý“ atd. v návaznosti na jim odpovídající barvy konkrétních předmětů. 
ideovém kontextu kultury. Nelze je tedy redukovat na neurofyziologické dění, ale podle tzv. principu spojitosti (connection principle) není možné je od něj oddělit (Searle, 2004, s. 169-174; Fisherman, 2012, s. 163-165; Slavík et al., 2013, s. 54-57). Objasnění této supervenience Fisherman i jiní opírají o Dawkinsovu teorii memu (Fisherman, 2012, s. 167-168; srov. Dawkins, 1989, s. 192; Jan, 2000, s. 1-3; Hawthorne, 2007, s. 52-104).

Teorie memu nabízí cesty k řešení klíčového problému společného pro epistemologii, didaktiku a kognitivní vědy: jak kauzálně vysvětlit působnost aktivního obsahu na lidskou mysl. Fisherman v této souvislosti podotýká, že Vygotskij nebo Lotman v teoriích sociokulturního učení „tvrdí, že psychická aktivita je reorganizována operacemi se znaky“, ale „nevyjadřují se nutně k samotné povaze mysli“. Oproti tomu teorie memů „nabízí materiální základ pro to, co reorganizace psychické aktivity znamená: memy přenastavují mozkovou hmotu a změny v mozkové hmotě jsou z podstaty změnami v psychické aktivitě“ (2012, s. 168). Jejím rozhodujícím argumentem je soutěž mezi memy (meme competition). Memy mezi sebou soutěží jak o prosazení se v sociokulturním poli prostřednictvím společenského dialogu provázeného sociokognitivními konflikty, tak o přítomnost v konečném prostoru mozku (Fisherman, s. 166-168).

V této stati se nemůžeme věnovat tomuto směru uvažování podrobněji, ale usilujeme o jeho počáteční propojení s dosavadním vývojem transdidaktické teorie obsahových transformací, protože jsme přesvědčeni, že se tím otevírají prríležitosti k soustavné zdůvodněné spolupráci s neurovědami a kognitivními vědami, která se již nyní v náznacích objevuje např. v pedagogické psychologii (srov. Plassová et al., 2017) a do budoucna by mohla didaktiku zásadním způsobem obohacovat. Kromě toho se prostřednictvím konstruktu mem (jak vysvětlujeme níže) ukotvuje klíčové téma, které je leitmotivem didaktiky i této statě: výklad vztahů mezi epistemickými operacemi s aktivním obsahem utvářejícím subjektivní zkušenost a sémanticko-logickými strukturami, které tuto zkušenost začleňují do sociokulturně sdíleného kontextu v oborech.

Termín mem označuje „jednotku“ aktivního obsahu, která (analogicky s genem) generuje procesy či aktivity svého druhu. V populaci se mem šírí prostřednictvím replikací: včleňováním téhož obsahu do jiné báze zkušenosti. Mem při replikacích reprodukuje aktivní obsah, v populaci zabezpečuje distribuci a přírůstek společenského vědění a u jedinců podmiňuje nové uspořádání zkušenosti s potenciálem objevných inovací: tvorbou nových memů (srov. Fisherman, 2012, s. 170-171). Termín mem tímto způsobem reprezentuje kognitivní změny na úrovni historického kulturního vývoje.

Původní Dawkinsova (1989) sociobiologická a následně Dennettova (1991) techno-informatická koncepce nahliží re-kreativní potenciál memu v analogii s genovými mutacemi a informačními procesy. Tento přístup s oporou v Gombrichovi kritizuje Hawthornová (2007, s. 222-223) jako zužující, nebot’ obchází klíčovou úlohu schémat tradovaných sociokulturním učením. Náhodně ve společnosti distribuovaný vliv 
14 memů se totiž kulturně uplatňuje na bázi soustavně edukací osvojovaných a upevňovaných schémat (srov. Gombrich, 1985; Kozbelt, 2008).

Schémata kotvená $v$ historické tradici kulturního kontextu jsou nutnou oporou pro re-kreaci zkušenosti aktivním obsahem. Pojem schéma tedy vyzdvihuje identitu, reprodukovatelnost a přetrvávání určité obsahové struktury během historického kulturního vývoje. Vysvětluje reproduktivní (transmisivní) stránku replikace memů. $\mathrm{Na}$ ni navazuje inovativní složka: tvorba aktivního obsahu nových memů prostřednictvím relačních změn vyrůstajících z autorských objevů (srov. Slavík et al., 2013, s. 134). Replikování aktivního obsahu nových memů je ve společenském dialogu provázeno sociokognitivními konflikty $v$ nekonečné zpětnovazební smyčce kognitivních změn (Fisherman, 2012, s. 166), viz obrázek 1.

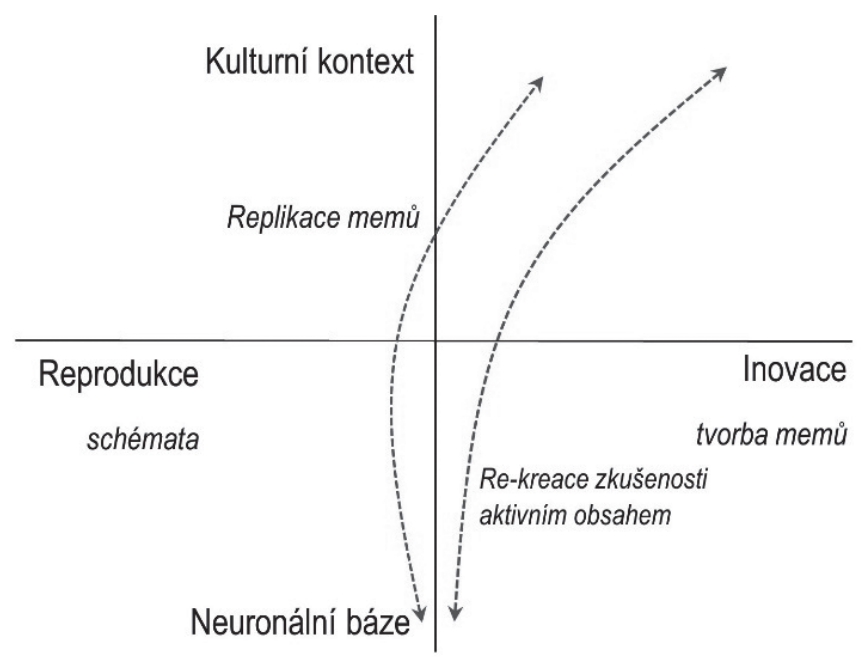

Obrázek 1 Tvorba a replikace memů v kulturním poli. Upraveno podle Slavík et al. (2013, s. 134).

Pojmy mem - schéma shodně s tradičními didaktickými a pedagogicko-psychologickými konstrukty predstava - prekoncept - koncept vymezují strukturní „jednotku“ obsahu vzhledem k celku: širšímu obsahu, resp. kontextu (Slavík et al., 2017a, s. 154-157; Štěpáník \& Slavík, 2017). Termíny mem - schéma však doplňují původní pojmovou triádu tradičně zkoumanou ze zorného úhlu osobní epistemologie o hledisko historické kulturní epistemologie, protože vysvětlují vzájemnou podmíněnost mezi epistemickými operacemi konstruujícími subjektivními zkušenost a sémanticko-logickými strukturami, které tuto zkušenost začleňují do sociálně sdíleného kulturního kontextu.

Kličcovým replikačním nástrojem memu ve vzdělávacím prostředí jsou učební úlohy. Učební úlohy aktivizují určitý obsah prostřednictvím jednání svých řešitelů: jsou 
to zvláštní kulturní praktiky přiznačné mísením nároků na reprodukci a na produkci (inovaci) obsahu replikovaného memem a funkčně podmíněného schématem (Slavík et al., 2017a, s. 149-162).

\subsection{Od obsahu jednání k obsahu zkušenosti: intencionální stav}

Učebními úlohami se obsah memu aktivizuje v jednání řešitelů úlohy a replikuje se učením zpưsobujícím kognitivní změny zkušenosti. Aktuální stav zkušenosti dosažený kognitivní změnou a charakterizovaný určitým „jednotkovým“ obsahem je nazýván intencionální stav (Searle, 2004, s. 117-122; Jacob, 2019). Intencionální stav musí být „o něčem“ (aboutness), což znamená, že je (relativně) rozlišitelný $(A \neq B)$ od všeho jiného, zaměnitelný $(A=B, A \approx B)$ se vším shodným a srovnatelný se vším podobným podle určitého klasifikačního pravidla (A, B jsou barevné).

Intencionální stav je charakteristický dvojakou epistemickou povahou: rozlišením mezi obsahem zkušenosti a způsobem jeho uchopení nebo zvládání - psychickou modalitou (Brentano, 1874/1973, s. 88-89; Husserl, 1993, s. 87-103; Searle, 2004, s. 117, 120). V pedagogice je príkladem dvojakosti intencionálního stavu proslulá Bloomova taxonomie vzdělávacích cílů rozlišená do dvou dimenzí: dimenze znalosti (obsahu) a dimenze kognitivního procesu (Anderson \& Krathwohl, 2001). ${ }^{8}$

Rozdíl mezi obsahem a psychickou modalitou, jak v návaznosti na Husserla konstatuje Čapek (2012, s. 140), je možné zachytit popisem. Kupř́ikladu uchopení nebo zvládání téhož obsahu „déšt' - prší“ může mít nespočet různých popisů: vím, že prší; představuji si, že prší; učím se o dešti; miluji déšt'; chráním se před deštěm; mluvím o dešti... Univerzalita použitelnosti jazyka způsobuje, že popisem lze vyjádřit jak to, co bylo výše označeno za obsah, tak způsob jeho uchopení nebo zvládání nazvaný psychická modalita - i ona se tedy mưže stát (metakognitivním) obsahem myšlení nebo konceptualizovaného jednání (srov. Chrz et al., 2015, s. 29).

Z popisů je zřejmé, že obsah se prostřednictvím psychické modality stává předmětem psychických a faktických operací: je aktualizován subjektem prostřednictvím akce. Tu lze $v$ řeči vystihnout činnostními slovesy, v didaktice i mezi učiteli v praxi běžně užívanými. Činnostní slovesa (mluví, počítá, řeší rovnici, experimentuje, analyzuje, hodnotí...) vypovídají o způsobu, jímž aktivní obsah memů re-kreuje osobní zkušenost a vyvolává ( $v$ určitém kulturním kontextu) kognitivní změny. Konstrukt intencionální stav je tedy dalším nutným východiskem pro vysvětlování souvztažnosti mezi epistemickými operacemi na úrovni subjektu a sémanticko-logickými strukturami kultury.

Z rozdílnosti popisů obsahu a psychické modality lze odvodit, že to, čemu říkáme obsah, je relativně stálý „nadčasový“ invariantní moment zahrnutý do probíhajícího „časovaného“ procesu svého zpracování, které lze jen uměle, jako film na jednotlivá políčka, rozčlenit na posloupnost intencionálních stavů. Jeden a týž obsah může být v př́islušné psychické modalitě zvládnutý lépe či hưře, tj. lze se učit, jak obsah zvládnout co nejlépe (fakticky, v prožívání, při komunikaci). 


\subsection{Intencionalita jako univerzální podmínka vztahu obsahu k cíli jednání}

Z dvojaké povahy intencionálního stavu a z univerzality jeho popisů vyplývá, že to, co zde nazýváme aktivní obsah memu, se během jednání (faktického a jazykového) re-kreativně začleňuje do zkušenosti subjektů jako potenciál jejich budoucích akcí. $\checkmark$ této podobě ho lze považovat za dispoziční cíl učení. Neoddělitelnost obsahu od cíle jednání je ve shodě s kurikulárním pojetím vzdělávacího obsahu: $v$ rámcových vzdělávacích programech je vzdělávací obsah vymezen jako propojený celek očekávaných výstupů a učiva (RVP G, 2007, s. 12; RVP ZV, 2005, s. 18).

Tento specifický vztah obsahu k cíli jednání a učení je vysvětlován konstruktem intencionalita (zaměřenost). Intencionalita je univerzálním předpokladem všech cílově orientovaných operací. ${ }^{9}$ Je základním filozofickým vysvětlením právě pro to, že lidskému vědomí, myšlení nebo chování přisuzujeme obsah (Searle, 2004, s. 117). Pojem obsah totiž presuponuje specifickou rovnocennost (izomorfii) mezi určitým momentem vnějšího prostředí, vnitřního intencionálního stavu a cíleného jednání. Schematicky to lze znázornit s oporou o upravenou Bloomfieldovu (1946, s. 15) parafrázi klasického Watsonova behaviorálního vzorce stimul (S) - reakce $(R)$. Znak 0 ve schématu znamená obsah, hranaté závorky symbolizují vnitřní dispoziční prostředí (personální zkušenost):

$$
\mathrm{S} / \mathrm{O} \rightarrow[\mathrm{O}] \rightarrow \mathrm{R} / \mathrm{O} \text {...CÍL }
$$

Searle (2004, s. 132) nabízí přiléhavou ilustraci uvedeného schématu na př́kladu intencionálního stavu žízně: „To, co způsobuje moje přání přáním napít se vody, je to, co bude uspokojeno pouze a jenom tehdy, jestliže se napiji vody. "Citované souvětí je pečlivě formulováno tak, aby zásadní zájmeno „to“ poukazovalo současně k stimulu (voda), k cílené reakci napití (vody) i k vnitřní potřebě (vody). Shodu $\checkmark$ poukazu $\mathrm{k}$ stimulu, cílené reakci i potřebě můžeme proto chápat jako ekvivalenci: týž obsah.

Konkretizace obecného vzorce intencionálního chování pro určitý obsah je dána podmínkami satisfakce (conditions of satisfaction; Searle, 2004, s. 119, 132-134). Podmínkami satisfakce je určeno, čeho se týká chování, tedy právě jeho obsah ve vztahu k cíli: ukojení žízně má jiné podmínky satisfakce než třeba zjištění pH vody (Slavík et al., 2017a, s. 83-84).

Filozofie či teorie intencionality má svůj původ ve scholastickém (Tomáš Akvinský) pojetí mentálního uchopení objektu: intencionální stav zahrnuje v sobě určitý obsah-objekt rưznými způsoby, např. v úsudku je něco potvrzeno nebo popřeno, ve vzpomínce je něco vzpomenuto, $v$ lásce je někdo milován atd. $V$ novověké filozofii byl konstrukt intencionality oživen v sedmdesátých letech 19. století F. Brentanem a produkuje řadu plodných otázek. Mezi nimi kupř. otázky k reprezentaci obsahu ve vztahu k cílové zaměřenosti vǔči objektu: Vyjadřují „odkaz na obsah“ a „zaměření k objektu“ dvě odlišné myšlenky? Nebo jsou to dva odlišné zpưsoby vyjádření jedné a téže myšlenky? (Jacob, 2019) 
Na bazální úrovni instinktů, jako u zmíněného ukojení žízně, podmínky satisfakce nezávisejí na sociokulturním učení a k replikacím odpovídajících vzorců chování proto postačují geny. Produkce a replikování memů závisí na tom, že obsah ve zkušenosti lze zvnějšnit a intersubjektivně sdílet interiorizacemi jazykových nebo jiných symbolických vyjádření obsahu. Podle Bloomfielda (1946) „jazyk přemost'uje mezeru mezi individuálními nervovými systémy“, protože výrazy zprostředkují obsah a vyvolají ekvivalentní odezvu jako jimi symbolizovaný podnět. Modifikované Bloomfieldovo schéma pak má tuto podobu (V zde označuje vyjádření či výraz určitého obsahu):

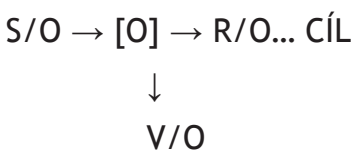

\subsection{Instrumentální praxe a instrumentalizace zkušenosti}

V oblasti vzdělávání se předmětem vyučování a učení stávají mnohé jiné než jazykové dovednosti. Proto výraz V/O pojímáme šíreji: jako syntézu pro-jevu zkušenosti s vnímaným jevem. V/O je tedy smyslově uchopitelné „něco“, co lze interpretovat a konceptualizovat jako informaci podmiňující rozhodování a intencionální jednání. ${ }^{10}$ Jak s odkazem k Vygotskému vysvětluje Štech (2013, s. 34), kupř. lžíce je „výzva k jídlu“: je to výraz historické praktické zkušenosti lidí s nabíráním pokrmu reprezentovaný jazykovým výrazem „lžíce“. ${ }^{11}$

Filozofické nebo teoretické východisko pro takto širokou generalizaci pro-jevů zkušenosti poskytují instrumentalistické přistupy založené na předpokladu, že interaktivní vztah lidí a světa závisí na instrumentech (srov. Jacob, 2019). Př́ikladem tohoto pojetí je teorie instrumentálního realizmu Ladislava Kvasze (2015, 2020), která má programové přesahy do diskurzu didaktiky (Kvasz, 2016, 2020). Kvasz považuje za prvotní druh nástrojů bílkovinné instrumenty - lidské tělesné orgány. Ty na základě součinnosti mezi lidmi produkují veškeré dalši instrumenty svázané

10 Oporu pro toto široké pojetí poskytují původní latinské pojmy expressio, expressus, odvozené od funkce razidla - opakované zformování (vytlačení) patrného tvaru z matrice (srov. Pražák et al., 1948 , s. 516). V tomto smyslu je každé vyjádření stejně jako každé jednání možné chápat jako „zvnějšnění“ či výraz obsahu zkušenosti interpretovatelné v př́slušném kontextu. Kupříkladu tenista při každém úderu do míče i při jiném herním pohybu na kurtu zvnějšňuje svou tenisovou zkušenost $v$ kontextu tenisových pravidel a tradic.

11 Výraz tím chápeme interaktivně jako sjednocení percipovaného jevu s pro-jevem zkušenosti $\checkmark$ něm. Výrazy plní svou informační úlohu pouze v souvislostech vzájemných poukazů, tj. v příslušném kontextu. Obsah se takto stává vědomě dostupným v jevech, které mu skýtají zjevný tvar (aspectual shape) vizuální, akustický, haptický, chut’ový... (srov. Searle, 2004, s. 172; Slavík et al., 2013, s. 135). Zjevný tvar je př́znakovým tvarem, splňuje-li podmínky rozlišitelnosti, zaměnitelnosti a srovnatelnosti s ohledem na funkčnost. $V$ príznakovém tvaru si pozorovatel v určitém kontextu odkrývá obsahovou identitu pozorovaného jevu (co to je) nebo jeho praktickou funkci (co si s tím počít) a může je podrobit následnému ověřování interpretováním, jednáním či proživáním. 
18 s jazykovou konceptualizací svého obsahu jako podmínkou sociokulturního učení a podmínkou historického vývoje instrumentů. ${ }^{12}$

Instrumenty svázané s konceptualizací jsou výrazem obsahu instrumentální zkušenosti, kterou samy zpětně v příslušném kontextu utvářejí a prohlubují. Na tomto základě vznikají a rozvíjejí se kulturní obory. Například kružítko i kresba kružnice jsou instrumenty, které reprezentují a utvářejí geometrickou zkušenost; GPS je instrument, který reprezentuje a utváří geografickou zkušenost. Instrumentální charakter zkušenosti je nutnou podmínkou pro soustavné nabývání a rozvíjení poznávání na základě společného intencionálního jednání (praktického a jazykového) v instrumentální praxi oborů. Díky instrumentální praxi oborů lidé dokážou podstatně přesahovat meze své přirozené zkušenosti a poznávat svět do hloubky (Kvasz, 2015, s. 43).

Instrumentalistické pojetí je pro transdidaktiku zásadním přínosem proto, že koncipuje generalizace např́č obory, ale se zachováním doménových specifik konstruování jejich obsahu. Proces, jímž se struktura aktivního obsahu oboru začleňuje do subjektivní zkušenosti, jsme nazvali instrumentalizace zkušenosti a zde upřesňujeme (Slavík, 2017, s. 313; Slavík et al., 2017a, s. 55; Rodová \& Slavík, 2018, s. 12-13): instrumentalizace zkušenosti je re-kreace zkušenosti aktivním obsahem memů prostřednictvím instrumentální praxe. Podmínkou instrumentalizace zkušenosti jsou kognitivní změny způsobované jednak tvorbou nových memů na úrovni historické kulturní epistemologie, jednak replikací memů sociokulturním učením na úrovni osobní epistemologie. Zkoumání vztahů mezi oběma úrovněmi je badatelskou výzvou pro transdisciplinární didaktiku.

Didaktika nahliží na kognitivní změny na základě svých elementárních kategorií. Chce-li přitom respektovat paralely mezi historickou a osobní epistemologií, předpokládá, že aktivní obsah memů re-kreativně mění žákovskou zkušenost kulturně ukotvenou ve schématech. Tento proces se v didaktické tradici nazývá transformace obsahu.

\section{Transformace obsahu a obsahový izomorfismus při replikaci memu}

Formálním dokladem existence obsahu memů je záznam v ústředních kurikulárních dokumentech - vzdělávacích programech. V nich jsou konkrétní formulace, které popisují obsah a jeho cílovou psychickou modalitu (RVP ZV, 2005, s. 27, 33, 78, kráceno): „...slovní zásoba a tvoření slov - žák správně tvoří slova a věty; prostorové

12 Instrumenty jsou utvářeny a užívány na pomyslném švu mezi kauzálními fyzikálními vztahy a sémanticko-logickými mentálními operacemi, jimiž se organizuje součinnost a komunikace mezi lidmi. Kupríkladu sloupec rtuti v teploměru svým pohybem reprezentuje kauzální fyzikální vztahy, ale nabývá kulturní význam pouze tehdy, když je významově interpretován a při myšlení a komunikaci je logicky propojen jak s př́slušnými znalostmi lidí o teplotě, tak s prožíváním jejích změn mezi komfortní zónou a extrémními stavy (srov. Štech, 2013, s. 42-43; Slavík et al., 2017a, s. 55-56). 
útvary - žák sestrojí obraz těles v rovině; pohybové činnosti - žák zvládá pohybové dovednosti a tvořivě je aplikuje atd.“"

$Z$ těchto formulací lze odvodit zdánlivou samozřejmost: obsah memů (potenciálně aktivní obsah) musí existovat ve sdílené kulturní podobě - intersubjektivně a má způsobovat re-kreativní změnu subjektivní zkušenosti. Pro replikování memů jsou tyto dvě podmínky nutné, avšak nepostačující, protože sice předpokládají „horizontální“ vztahy mezi významy, ale nezahrnují jejich „vertikální“ ukotvení ve smyslově vnímané realitě, které je nezbytné pro reciprocitu perspektiv ${ }^{13}$ (Schütz, 1953, s. 7-9; Slavík et al., 2017a, s. 32, 91-94). ${ }^{14}$

\subsection{Subjektivní, intersubjektivní a objektivní způsob existence aktivního obsahu}

Spojení „horizontálního“ a „vertikálního“ hlediska vede k rozlišení tří kličových způsobů existence obsahu memů: subjektivní, intersubjektivní, objektivní. ${ }^{15}$ Znázorněme strukturovanou jednotku obsahu v duchu Vennova diagramu' ${ }^{16}$ (obrázek 2; jednotka obsahu = tečkovaná plocha). Tím zjevně rozlišíme tři uvedené způsoby existence obsahu: P1 - objektivní (co je vnímatelné), P2 - intersubjektivní (co je vyjádřitelné a sdělitelné), P3 - subjektivní (co je myslitelné a představitelné). Oboustranná šedá šipka konceptuálně propojuje fyzickou existenci objektu $(\mathrm{P} 1) \mathrm{s}$ jeho symbolickou reprezentací vyslovením, zápisem nebo zobrazením (P2). ${ }^{17}$

13 Reciprocita (poznávacích) perspektiv závisí na dvou podmínkách: ontické a antropické. Ontickou podmínkou je existence téhož objektu jako svorníku dvou a více rozdílných zkušeností, antropickou podmínkou je existence společného bio-psycho-sociálního základu a společné kultury konstituované sdíleným jazykem (Schütz, 1953, s. 7-9; Slavík et al., 2017a, s. 32-33).

14 „Vertikální“ ontické ukotvení objasňuje Searle (2004, s. 189-190): subjekty mají smyslový prístup k témuž objektu vnímání a mohou se prostřednictvím jazyka (public language) shodnout na jeho obsahové identitě („Je to stůl?“ - „Ano.“ - „Je dřevěný?“ - „Ano.“). Dodejme, že tento argument má silné pragmatické zázemí: bez onticky závazných shod na identitě objektu není možná součinnost a spolupráce při dosahování společných cílů - a naopak, nebyla by žádná šance třeba pro to, aby komunikace a součinnost stovek lidí vedla k úspěšné vesmírné misi Gagarina nebo Apolla 11.

15 Rozlišení univerza do tří vzájemně spjatých oblastí navrhl díky Bolzanově inspiraci již K. R. Popper (1998) v podobě tří světů. Jeho pojetí zhodnotili pro didaktiku matematiky Hejný a Kuřina (2000) a pro obecnou didaktiku Janík a Slavík (2009).

16 Ve filozofické tradici portroyalské logiky byl obsah pojmu chápán jako průnik rozsahů jeho nadpojmů; např. pojem černý kůň je průnikem třídy, jejímiž prvky jsou černé objekty, a třídy, jejímiž prvky jsou koně (Materna, 1995, s. 18).

17 Intersubjektivní sdílení obsahu (P2) zobrazujeme průnikem klasifikačních tříd reprezentujících subjektivní hledisko (P3). Odpovídá to klasickému vymezení obsahu pojmu na základě rozsahu (Materna, 1995, s. 18). Subjektivní hlediska se mohou v detailech vzájemně lišit, ale má-li být zachována šance na dorozumění, musí mít společný průnik. Konkrétně: desítku objektů v různých odstínech červené mohou dva lidé tř́idit pod odlišnými pojmy (sytě červená, červeno-oranžová, červeno-fialová atp.), ale měli by se významově shodnout alespoň v těch, které jsou sytě červené (srov. Slavík et al., 2013, s. 69-71). 


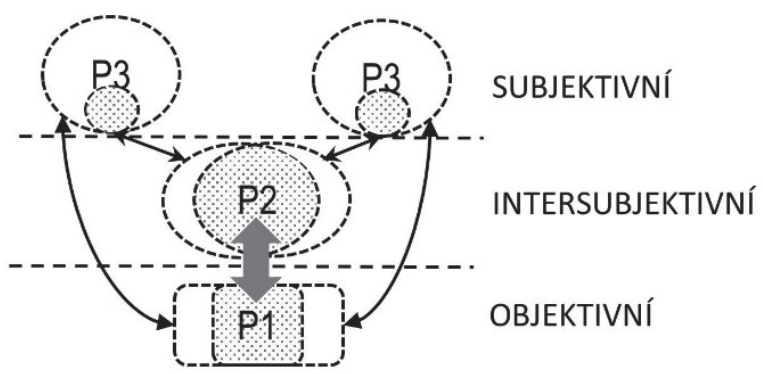

Obrázek 2 Tři způsoby existence obsahu

Ze schématu lze vyčíst, že P1, P2, P3 jsou sice rozdílně fyzicky situované, ale rovnocenně ideově vyložené. Pro tento typ rovnocennosti v návaznosti na Hofstadtera uživáme pojmenování izomorfismus (Hofstadter, 2012, s. 30, 71; Slavík et al., 2013, s. 51-56; Slavík et al., 2017a, s. 102-105).

S ohledem na rozdílnou situovanost obsahu P1, P2, P3 je zřejmé, že obsah mezi těmito způsoby existence během činnosti přechází, aniž ztrácí svou identitu. Např́klad zápis $1+1=2$ (P2) je v tomto smyslu izomorfní s fyzickou operací seskupení dvou kuliček počitadla (P1) a s mentální operací téhož výpočtu (P3). Tento typ sémantické, logické a operační rovnocennosti mezi různými způsoby existence identického obsahu během činností s ním nazýváme transformace obsahu.

\subsection{Transformace obsahu a izomorfismus operační nebo instrumentální}

Termín transformace obsahu má v didaktice pevnou tradici díky sousloví didaktická transformace obsahu, ale jeho obecný rozsah je ve výše uvedeném smyslu mnohem širší: znamená jakoukoliv proměnu obsahu, pro niž za daných podmínek či okolností platí izomorfismus (srov. Slavík et al., 2017a, s. 270-272). Rozlišujeme dva druhy izomorfismu, vzájemně závislé: izomorfismus operační, izomorfismus instrumentální (Slavík et al., 2017a, s. 103). ${ }^{18}$

Operační izomorfismus je rovnocennost mezi subjektivní, intersubjektivní a objektivní existencí téhož obsahu. Bez ní není možné vysvětlit replikaci memu prostřednictvím sociální interakce: proč operace s fyzickými instrumenty (P1) v intersubjektivní úrovni (P2) mají důsledky pro re-kreaci obsahu subjektivní zkušenosti (P3) - např. proč se učitel může spoléhat, že navrhne-li žákovi opravu nějaké chyby

18 Termín transformace obsahu je určován izomorfismem zdůrazňujícím identitu obsahu v re-kreativním procesu. Avšak právě proto, že proces je re-kreativní, můžeme za určitých okolností pokládat dưraz i na rozkolísávání obsahové identity. Pak by bylo možné stejným právem mluvit o rekonstrukci obsahu a zdůrazňovat tím inovativní stránku kulturní praktiky při obsahové transformaci (srov. Slavík et al., 2017a, s. 270-272). 
a žák tuto opravu přijme, pozmění se žákova zkušenost a žák přišš̌ stejnou chybu neudělá.

Operační izomorfismus závisí na kauzálních vazbách mezi intencionálním stavem a odpovídajícím procesem konstrukce obsahu, během nějž se „,atemporální“ struktura konfiguruje do zjevného tvaru; např. kreslím od ruky nebo kružítkem svou aktuální představu obecné struktury - kružnice. Tím se temporální „žitá zkušenost“ re-kreuje interakcí s relativně mnohem trvalejším stavem pravidel, zákonitostí a formálních logických vztahů (Slavík et al., 2013, s. 61-63, 115).

Instrumentální izomorfismus je rovnocennost mezi různými variantami objektivní existence téhož obsahu. Bez odvolání na instrumentální izomorfismus není možné vysvětlit kulturní replikaci memu: proč lze didakticky propojovat vyjádření obsahu žákovské zkušenosti $(\mathrm{P} 3 \rightarrow)$, např. spontánní zpěv, s relevantním obsahem kultury, resp. oborů («P2), kupř. s notovým zápisem zazpívané melodie.

Instrumentální izomorfismus má dvě úrovně. Nejprve rovnocennost mezi fyzickou existencí objektu (P1) a jeho symbolickou reprezentací (P2): P2 je P1. Napríklad slovo „kůň“, „horse“, „cheval“ (P2) je (v daném kulturním kontextu) izomorfní s tímto zvíretem (P1) a totéž platí pro zobrazení koně. Na tento základ navazuje rovnocennost mezi různými intenzionálními alternativami symbolické reprezentace téhož obsahu (P2 ${ }^{1}, P 2^{2}, P 2^{3}$ atd.): vyjádření „téhož jinak“, např. slova jeho synonymy nebo slova obrazem (srov. Slavík et al., 2017a, s. 84-88; Janík et al., 2020, s. 4-6).

\subsection{Dvojúrovňová korespondence v izomorfismu při replikaci memu}

Pro oba druhy izomorfismu platí dvojúrovňová korespondence (Hofstadter, 2012, s. 72; Slavík et al., 2013, s. 54; Slavík et al., 2017a, s. 91-96). Jednak „vertikální“ korespondence mezi reprezentací obsahu jevem a z jevu interpretovaným obsahem; nazveme ji sémantická korespondence. Jednak „,horizontální“ korespondence mezi interpretovaným obsahem a jeho výkladovým kontextem (teorémy), kterou nazveme logická korespondence. Logická korespondence propojuje elementy obsahu (významy, koncepty) uvnitř určité soustavy instrumentálních operací a jejího výkladového rámce, tj. uvnitř určité teorie (at' již „velké“, nebo jen subjektivní teorie). Funkční spojení obou úrovní nazýváme sémanticko-logická struktura (viz níže).

Př́klad dvouúrovňové korespondence v inspiraci Fregem uvádí Hofstadter (2012, s. 78, 479): počítání kapek stékajících na okně při dešti. Na úrovni sémantické korespondence $v$ interpretačním kontextu matematiky platí rovnocennost kapka je jedna. Tehdy musí platit též logická korespondence pro matematický kontext: operace sčítání. Ta je ale zrušena ve chvíli, kdy dvě stékající kapky splynou do jedné. Což je výzva k přehodnocení kontextového rámce pro instrumentální operace - místo sčíání kapek sčítat objem vody v nich. Povšimněme si zásadní změny instrumentária a instrumentální praxe: $k$ tužce a papíru přibyla pipeta a odměrka spolu s fyzikálními znalostmi a dovednostmi k jejich užívání. 
Zjišt'ování a měření objemu látek u nás standardně patří do kurikula fyziky 6. ročníku základní školy, takže na uvedený př́klad se dá pohlížet též jako na ilustraci replikační procedury příslušného memu při realizaci kurikula. Mem jakožto strukturovaná jednotka aktivního obsahu se ve vzdělávacím systému replikuje v odpovídajícím kulturním kontextu (zde v instrumentálním kontextu matematiky a fyziky) prostřednictvím konkrétních výukových situací zakotvených v učebních úlohách.

Učební úlohy vyzývají žáka k činnosti s aktivním obsahem: s obsahem, který má způsobit kognitivní změny v žákovské zkušenosti, jestliže žák bude s obsahem zacházet podle zadaných podmínek satisfakce. To znamená, bude-li s nimi zacházet tak, aby $v$ př́slušném instrumentálním kontextu zachoval sémantickou a logickou návaznost mezi východisky (zadáním učební úlohy) a cílovým stavem svého intencionálního jednání: zvládnutím obsahu v podobě znalosti, gramotnosti, kompetence apod. Dosažení tohoto cíle by nebylo možné, kdyby edukační působení memu v učební úloze nebylo založeno na existenci odpovídajícího schématu. Tomu je věnována následující kapitola.

\section{Replikace memu aktivním obsahem prostřednictvím učebních úloh}

Mem jakožto strukturovaná jednotka aktivního obsahu je produktivní a prosazuje se v konkurenci a při spolupráci, jestliže plodí velkou šíři svých realizací - jestliže se v kultuře vydatně replikuje. Tyto replikace se ve svém zjevném tvaru („fenotypově“) navzájem liší, ale mají-li být rozpoznatelné coby replikační varianty téhož memu, musí zachovávat shodnou replikační bázi - identitu obsahu. Ta je identifikována na základě dvojúrovňové korespondence v operačním a instrumentálním izomorfismu.

Rozpoznávání identity určitého obsahu prostřednictvím dvojúrovňové korespondence závisí na substrátu předchozí zkušenosti, do níž má být replikovaný mem inkorporován, aby mohl způsobit re-kreativní změnu. To znamená, že musí existovat nezbytně nutná sémantická a logická spojnice mezi dosavadním obsahem zkušeností (předporozuměním - prekonceptem) a nově do ní vstupujícím aktivním obsahem „infikujícího“ memu. Tento sémanticko-logický svorník mezi žákovskou zkušeností a vzdělávacím obsahem v zóně nejbližšího vývoje (ve smyslu Fischermanovy interpretace Vygotského) byl výše nazván schéma. ${ }^{19}$

19 Ve filozofii nebo $v$ teoretických disciplínách pojem schéma $v$ daném smyslu znamená relativně stabilní významovou, logickou a funkční strukturu určitého obsahu s možností re-kreace. Schéma musí být izomorfní pro všechny tř́ základní způsoby existence obsahu: subjektivní, intersubjektivní, objektivní. Proto je nutným základem jak pro porozumění světu, tak pro dorozumění se mezi lidmi. Pojem schéma $v$ tomto pojetí má původ $v$ tvarové psychologii a filozofii, odkud se rozšiřil do dalších oborů včetně didaktiky (Goodman, 1976/2007; Piaget, 1983; Anderson \& Pearson, 1984; Strawson, 1997; Hejný, 2008). 
Pro operacionální vysvětlení pojmu schéma vyhovuje Goodmanovo (1976/2007) objasnění schématu jako rodiny (generického rámce) sémanticko-logicky seskupených označení (pojmů, konceptů). Rozsah jejich interaktivního promítání do světa je Goodmanem nazýván sféra: sféra je „souhrn oblastí extenze jednotlivých označení ve schématu“ (s. 69). Schéma (jak intersubjektivně sdílené, tak držené jednotlivými subjekty) a sféra (rozsah praxe pokrytý schématem) jsou izomorfní.

Držení schématu ve zkušenosti ( $v$ mozku, $v$ těle) subjektem nazýváme mentální schéma (Slavík et al., 2017a, s. 185-189). Mentální schéma je „kognitivní gestalt“, je to komplexní dispozice pro zvládání př́slušného obsahu alespoň v nezbytně nutné minimální míre. Mentální schémata jsou vysvětlením pro př́slušnou znalost obsahu (procedurální i deklarativní): subjekt má znalost obsahu, jestliže jeho mentální schéma vhodně koresponduje jak $s$ intersubjektivně sdíleným schématem (v oborech či kulturních oblastech), tak s jeho sférou v činné instrumentální praxi.

Mít určité mentální schéma znamená mít potenciál provádět odpovídající činnosti (srov. Goodman \& Elginová, 2017, s. 118-119; Kohout et al., 2019, s. 26). Subjektivní existence mentálního schématu se tedy projevuje kulturními praktikami: praktikováním dovedností vytvářet, posuzovat a revidovat řešení př́slušných úkolových situací nebo k němu rozumně argumentovat (Slavík et al., 2017a, s. 142-145). Nejhlubší báze mentálního schématu je dána genem, ale rozvíjí se prostřednictvím obsahu memů (např. aproximální numerický systém jako vrozené neurální východisko schopností, které se rozvíjejí instrumentální praxí matematiky; srov. Plassová et al., 2017).

Klíčovou úlohou mentálních schémat $v$ kultuře je nejenom organizovat intencionální jednání subjektu, ale zejména zabezpečit nutnou míru reciprocity perspektiv při vzájemné součinnosti a komunikaci. Proto mentální schémata navzdory vysoké míře intersubjektivní variability musí mít nějaký společný invariant zajišt'ující dorozumění a operační návaznost v praktických interakcích s reálným světem. Základem takového invariantu je sémanticko-logická struktura.

Sémanticko-logická struktura je způsob uspořádání významově a logicky souvisejících částí (prvků) propojených navzájem a s odpovídajícím kontextem podle určitých pravidel (srov. Peregrin, 1999, s. 80, 107-108). Sémanticko-logická struktura je hypotetický konstrukt, který vysvětluje pravidelnost při řešení úkolových situací, resp. úloh: je-li sémanticko-logická struktura funkční, vede k úspěchu, a tedy k opakování (pravidelnosti) určitého způsobu jednání. Tato pravidelnost je nutnou podmínkou reciprocity perspektiv $v$ intersubjektivní součinnosti.

Sémanticko-logické struktury pocházejí z kulturního rámce, resp. oboru či oblas$\mathrm{ti}$, a rozvíjejí se $\mathrm{v}$ instrumentální praxi. $\mathrm{V}$ ní jsou intersubjektivně sdílené, dlouhodobě pamětně uchovávané a neustále kriticky revidované, takže se během kulturní historie rozvíjejí a mění (srov. Kuhn, 1997; Kvasz, 2008, 2020). 


\subsection{Sémanticko-logická struktura a sémanticko-logické sítě při reflektivní analýze učebních úloh}

Replikace memu je metafora pro historickou kulturní genezi poznatků mezi lidmi. Učební úlohy jsou replikační „transportéry“ (analogie messenger-RNA) obsahu memu, resp. jeho ucelených dílčích složek; jeden mem se zpravidla replikuje mnoha rozmanitými úlohami. Nazveme je $M$-úlohy (tř́́da úloh pro replikaci téhož memu). To znamená, že učební $M$-úlohy musí vyrůstat ze sémanticko-logické struktury ve schématech př́slušného memu a s oporou v ní mají připravit podmínky pro vznik a rozvoj vhodné úkolové situace, v níž se mem replikuje prostřednictvím učení.

Sémanticko-logická struktura je hypotetický konstrukt, který lze interpretovat na základě reflektivní analýzy úkolové situace a analýzy kulturních praktik, které tuto situaci řeší. Interpretovaná sémanticko-logická struktura může být zobrazena podobou grafu (s uzly a hranami), obvykle chápanou volněji jako dvoj-/trojrozměrná sít' vzájemně na sebe poukazujících pojmů, resp. konceptů, které reprezentují určité složky obsahu a s nimi souvisejících psychických modalit či operací. Takový grafický záznam interpretovaný z řešení určité úkolové situace, resp. úlohy, nazýváme sémanticko-logická sít'.

Vzhledem $\mathrm{k}$ tomu, že učební úlohy mají být konstruovány tak, aby měly logicky a významově korektní řešení a aby jejich chybná řešení bylo možné vysvětlit, lze každou variantu jejich řešení (správnou i chybnou) reprezentovat $v$ podobě sémanticko-logické sítě. Sémanticko-logickou sít' lze z konkrétního řešení interpretovat, zaznamenat ji a kriticky srovnávat s jinými variantami řešení (obrázek 3; Kohout et al., 2019).

Sémanticko-logická sít' je reprezentant operací, které realizoval řešitel úlohy. Poskytuje klíčové záchytné body pro jejich vyhodnocení a hledání případných korektivních postupů, které by vedly $\mathrm{k}$ lepší re-kreaci zkušenosti řešitele aktivním obsahem. Analýza sémanticko-logických sítí je založena na kvalitativní komparaci relativně ideální varianty (reprezentující správné řešení) s ostatními variantami (srov. Kohout et al., 2019) nebo na kvantitativně zpracované komparaci zkoumaných variant (srov. Nohavová, 2018; Chocholoušková \& Hajerová Müllerová, 2020).

\subsection{Aktivní obsah jako faktor kognitivní změny}

Mem lze $v$ analogii s genem pojímat jakožto program. Mem je programem pro řešení určitého typu úkolových situací nebo - ze vzdělávacího hlediska - učebních M-úloh. Z toho vyplývá, že řešitel úlohy, kterou zkonstruoval někdo jiný, musí mít ve své zkušenosti alespoň nějakou základní funkční část memu (prekoncept: pre-schéma), aby mohl $M$-úlohu správně rozpoznat a řešit. $V$ takovém př́padě řešitel dokáže zaujmout pozici autora úlohy a re-produkovat jeho řešitelský postup. To je nutná podmínka uplatnění aktivního obsahu úlohy pro re-kreativní změnu zkušenosti jejího řešitele. 
c) hřebik se stane m agn etem

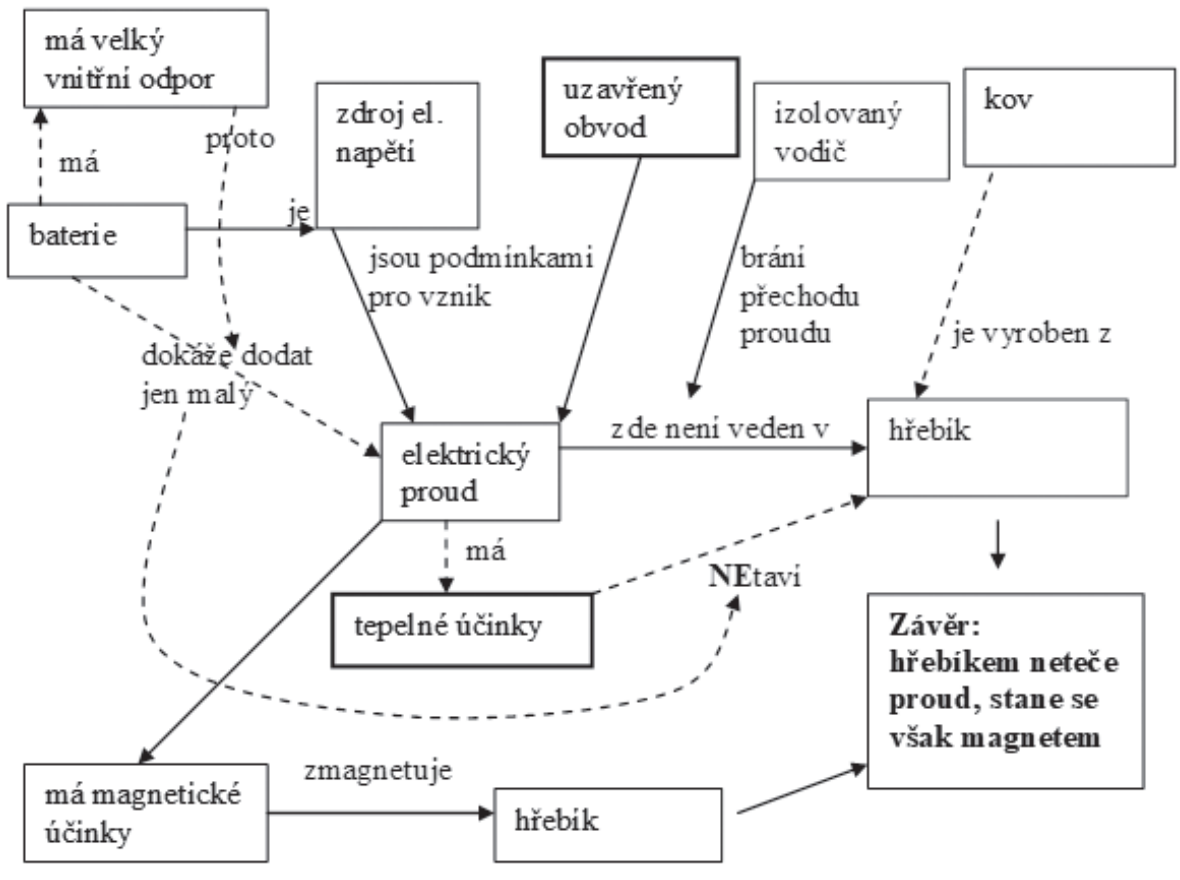

d) s hř ebikem se nestane nic

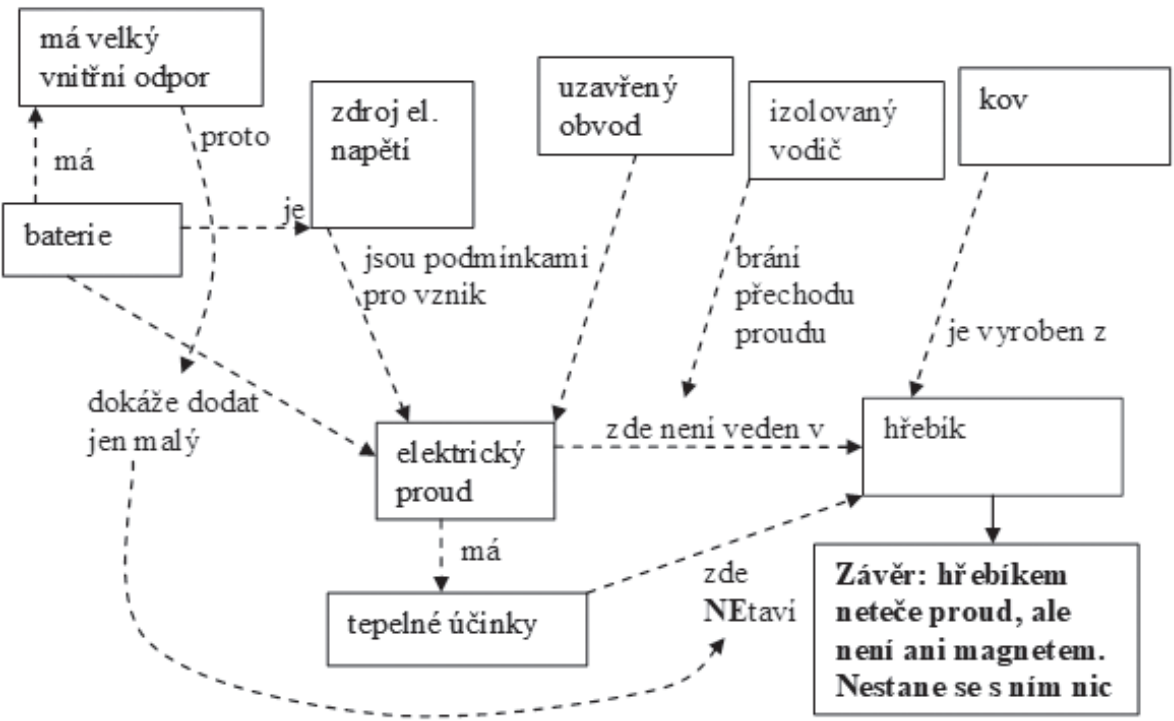

Obrázek 3 Př́klad sémanticko-logických sítí řešení učební úlohy z fyziky. Převzato z Kohout et al. (2019, s. 28-29). 
Uvedená schopnost 1) zaujmout kognitivní situační pozici svého protějšku, 2) simulovat jeho intencionální stav a 3 ) představit si a kriticky vyhodnocovat různé hypotetické varianty jeho jednání je nutnou podmínkou pro řešení učebních úloh. ${ }^{20}$ Tehdy zadání učební úlohy vede $k$ jejímu řešení díky tomu, že řešitel „ví, co se $v$ ní myslí“. Řešitel proto musí mít $\mathrm{k}$ dispozici zkušenost poučenou předcházející praxí: instrumentální zkušenost. Kupř́íladu úloha-otázka „jaké číslo si myslím?“ není racionálně řešitelná a nemá didaktickou hodnotu, na rozdíl od úlohy „jaké přirozené číslo si myslím, je-li jeho dvojnásobkem 4?“. Druhá otázka je řešitelná jen díky instrumentální praxi matematiky.

Dennett (2004, s. 33-46) tuto strategickou interpretační pozici nazval intencionální postoj. Intencionální postoj podle Dennetta je strategie interpretace chování nějakého protějšku, $\mathrm{k}$ němuž se přistupuje se znalostí své vlastní intencionality. Dennett považuje intencionální postoj za univerzální strategii pro výklad pravidelností v chování jakéhokoliv dynamického systému (živého i neživého). Je tedy obecnou podmínkou pro řešení všech úkolových situací v instrumentální praxi. ${ }^{21}$

Pouze s oporou $v$ intencionálním postoji ukotveném $v$ instrumentální praxi může řešitel porozumět, oč $v$ úloze jde a jak ji řešit, protože si dokáže komplexně představit a významově interpretovat její obsah, zkusmo jej analyzovat na strukturu částí (tedy sémanticko-logickou strukturu) a $\mathrm{k}$ nim zvolit vhodné procedury řešení („,nejdř́v toto tímto způsobem, pak tamto...“). Obsah úlohy se tím stává aktivním obsahem a vede $k$ re-kreaci zkušenosti jejího řešitele charakterizované odpovídající kognitivní změnou.

\section{Diskuse}

V předcházejícím textu jsme stručně charakterizovali teoretický rámec pro porozumění procesům, jimiž se kulturní obsah transformuje do podoby vzdělávacího obsahu a prostřednictvím součinnosti učitelů se žáky udržuje a rozvíjí kulturní historii. Ústřední kategorií tohoto výkladu je pojem obsah.

Pojem obsah je pevně ukotvený v didaktické tradici zejména ve slovním spojení vzdělávací obsah. Ve vzdělávacím diskurzu je však užíván vesměs jen jako intuitivní pojem, bez preciznějšího objasnění v teorii a následně bez vyjasněné operacionalizace vůči empirickému výzkumu výuky nebo evaluaci její didaktické kvality. Teoretická nevyjasněnost panuje zejména u návaznosti pojmů vzdělávací obsah chápaný

20 Východiskem $\mathrm{k}$ tomu je kognitivní penetrabilita představ, tj. schopnost uvědomit si jejich konceptuální obsah (conceptual content; srov. Currie \& Ravenscroft, 2011, s. 89, 103-107; Slavík et al., 2013, s. 88-90).

21 Intencionální postoj vychází z psychologického principu mentalizace - schopnosti člověka správně přiřazovat obsah duševních stavư (myšlenek, přesvědčení, dojmů, emocí, přání, cílů atp.) sobě a ostatním lidem. Intencionální postoj je však obecnější: vede totiž k intencionální interpretaci všech vnějších procesů. Řečeno ve zkratce, naučím-li se odhadovat a předvídat akce druhého člověka, mám předpoklady i k odhadům a předvídání akcí jiných živočichů, a nakonec i neživých věcí, např. pohybů planet nebo procesů chemických reakcí. 
jako závazná součást formalizovaného kurikula, znalost obsahu (procedurální, deklarativní, resp. konceptuální) pojímaná jako součást zkušenosti žáka, a vzdělávací cíl, který se vztahuje $\mathrm{k}$ žákovi a nezbytně souvisí se vzdělávacím obsahem, ale nemúže s ním být totožný, protože je charakterizován kognitivní změnou, která zasahuje do psychické modality intencionálních stavů.

Pro osvětlení didaktické intuice jsme $v$ této stati návazně $\mathrm{k}$ našim předcházejícím publikacím nabídli ucelený teoretický rámec opřený o několik interdisciplinárních inspirací, které jsme výše stručně objasnili. Všechny by si zasloužily mnohem zevrubnější výklad. $\mathrm{S}$ vědomím přirozených limitů rozsahu textu se však $v$ diskusi budeme věnovat jen té, která se nejúžeji vztahuje k problému „vyprazdňování obsahu“: typologii kognitivních změn v kontextu instrumentálního realizmu Ladislava Kvasze. Autor ji představil didaktickému publiku v Orbis scholae 1/2020. Její klíčový teorém o paralele mezi typy kognitivních změn v historické kulturní epistemologii a v osobní epistemologii považujeme za principiální problém pro transdidaktický teoretický diskurz.

Nezabýváme se zde formalistickými polemikami o této paralele (Greiffenhagen \& Sherman, 2006) ani obecnými pedagogickými diskusemi k ní (srov. Mason, 2007), které odvádějí pozornost didaktiky mimo hlavní otázku: $V$ jakém teoretickém a metodologickém rámci lze typové rozlišení kvality kognitivních změn na intersubjektivní (kulturně-historické) úrovni využivat pro didaktické výzkumy kvality kognitivních změn na subjektivní (personálně-vývojové) úrovni? Teoretický a metodologický rámec pro řešení této otázky zde formulujeme, zdůvodňujeme a diskutujeme.

Vycházíme $z$ předpokladu, že kognitivní změny jsou nezbytným korelátem re-kreace zkušenosti aktivním obsahem a nutnou podmínkou znalosti obsahu (konceptuální, deklarativní, procedurální): znalost obsahu jakožto výsledek učení presuponuje re-kreativní změnu zkušenosti aktivním obsahem. Tento „subjektivně držený “ obsah se však konstituuje intersubjektivně: prostřednictvím instrumentální praxe $v$ kulturních oborech či oblastech, které re-kreativně rozvíjejí a medializují instrumentální zkušenost. Ve vzdělávání se instrumentální zkušenost replikuje prostřednictvím M-úloh coby kulturní program - mem. M-úlohy ve vzdělávacím prostředí mají způsobovat instrumentalizaci žákovské zkušenosti.

Zavedením metafory memu $v$ návaznosti na ostatní analytické jednotky (představa, prekoncept, koncept, schéma) a na konstrukt $M$-úloh usilujeme o řešení didaktického problému funkční syntézy tří ontologických pozic, které Kvasz (2015, s. 42-43) nazývá „pojmy reality“: objektivní, intersubjektivní, subjektivní. Kvasz $(2016,2020)$ je však v didakticky zaměřených textech nevyužil pro výklad vztahů mezi epistemickými operacemi utvářejícími subjektivní zkušenost a sémanticko-logickými strukturami, které tuto zkušenost začleňují do sociálně sdíleného kontextu. Proto rozlišení tři ontologických pozic, které má korespondence $v$ didaktické tradici (Hejný \& Kuřina, 2000; Janík \& Slavík, 2009), začleňujeme do aktualizovaného výkladového kontextu transdidaktiky se zvláštním ohledem na jejich operacionalizaci pro výzkumy výuky a hodnocení její kvality. 
Podle Kvasze (2015, s. 18, 44, 55 a jinde) nemá být diferenciace a vzájemná relace tří pojmů reality (zasazená do koncepce tzv. kompozitivní formy jazyka) chápána jako konkurence různých obrazů skutečnosti, ale jako výchozí ontologický konstrukt nutný $\mathrm{k}$ pochopení, z jaké perspektivy určitá instrumentální praxe otevírá př́stup $\mathrm{k}$ realitě. Didaktika, resp. transdidaktika, nemá důvod být $\mathrm{s}$ tímto ontologickým východiskem ve sporu. Náš př́stup k němu však akcentuje jeho epistemologické důsledky. Ty plynou z faktu, že jakékoliv (nejenom matematické) 22 kulturní poznávání závisí na symbolických, resp. mentálních reprezentacích (srov. Kvasz, 2015, s. 27). Proto rozlišení objektivní, intersubjektivní a subjektivní reality $v$ transdidaktice pojímáme ve výše popsaném smyslu jako tři způsoby existence obsahu, o němž můžeme vědět, zabývat se jím a učit se ho jen proto, že ho sdílíme užíváním kulturních instrumentů.

Takto chápaným začleňováním instrumentalistického hlediska do kontextu transdidaktického výkladu usilujeme o zužitkování inspirací z teorie intencionality. Ta, jak jsme výše vysvětlili, je pro transdidaktiku oporou pro vysvětlování návaznosti mezi obsahem a cílem intencionálního jednání. Tuto návaznost nelze zdůvodnit bez existence instrumentů a instrumentální praxe, v níž se vztah mezi obsahem a cíli realizuje podle podmínek satisfakce $v$ procesu instrumentalizace zkušenosti. Tím se vracíme $\mathrm{k}$ ústřednímu tématu: kognitivním změnám, které instrumentalizaci zkušenosti provázejí.

Opakovaně jsme uvedli, že hlavní prínos diskutované Kvaszovy (2020) statě pro didaktiku spatřujeme $v$ ambici vysvětlovat kognitivní změny na úrovni osobní epistemologie (srov. Juklová, 2019, s. 14-103) prostřednictvím typologie kognitivních změn na úrovni historické kulturní epistemologie. Kvasz (2020) argumentuje, že kulturně-historický přístup $\mathrm{k}$ typologii kognitivních změn umožňuje vidět kognitivní změny v čistotě jejich instrumentálního ukotvování, což dovoluje oddělit a izolovat jejich jednotlivé druhy nad rámec možností, jimiž disponuje samotný výzkum ontogeneze osobní epistemologie. Souhlasně konstatujeme, že tato inspirace přináší didaktice silné podněty $\mathrm{k}$ hluboké analýze procesu obsahových transformací a může vést $\mathrm{k}$ systematickému úsilí o překonávání nepř́hodných rozdílů mezi diskurzem oborových didaktik a diskurzem pedagogické psychologie.

Kvasz rozvíjí své pojetí výkladu typologie kognitivních změn v užším rámci instrumentální praxe matematiky spolu s fyzikou, ale $v$ řadě ohledů je chápe jako obecnou teorii kognitivních změn napřič obory. ${ }^{23} \mathrm{~V}$ tomto bodě spatřujeme nejdiskutabilnější, ale zároveň nejinspirativnější podnět. Ke Kvaszově typologii kognitivních změn můžeme totiž přistupovat z pozice, která se - z didaktického zorného úhlu - bliží

22 Závislost poznávání na mentálních reprezentacích není podle našeho mínění totéž, co ontická závaznost mentálních reprezentací při poznávání. Matematické poznávání je závislé na mentálních reprezentacích shodně jako jiné obory instrumentální praxe. Ale pouze mentální reprezentace $v$ matematice prokazují silnou ontickou závaznost - deduktivní operace $v$ nich „fungují na svět" při prognózách.

23 Jak upozornil Slavík (2017, s. 318-319) pojetí instrumentální praxe u Kvasze (2015) kolísá mezi dvěma ne zcela ujasněnými pozicemi: široké (např́č obory) oproti výběrové (pro matematiku s fyzikou). Tato nevyjasněnost přetrvala do zde diskutovaného díla (Kvasz, 2020). 
antické koncepci mathémat jakožto „naučitelného věděni“.. Pak by instrumentální praxe zahrnovala i všechny další obory či oblasti přiváděné didaktikou do vzdělávacího diskurzu (Slavík, 2017, s. 319).

Přijmeme-li toto širší pojetí Kvaszova instrumentálního realizmu, lze jeho přístup $\mathrm{k}$ výkladu kognitivních změn funkčně zasadit do teoretického a metodologického kontextu transdisciplinární didaktiky. Důvod je ten, že usiluje o zobecnění napříc různými obory, ale současně odmítá výlučně psychologickou, resp. pedagogicko-psychologickou generalizaci, jestliže opomíjí oborové hledisko a nebere v úvahu historický vývoj instrumentální praxe. Konkrétním argumentem této kritiky je slepota pro rozlišení druhů kognitivních změn, jejichž izolování a klasifikace „př́stupy kognitivní psychologie nelze dosáhnout“ (Kvasz, 2020).

Kvasz (2016) vytýká kognitivní psychologii, že u žáků nerozpoznává ty kognitivní změny, které lze zjistit a rozlišovat na úrovni historické kulturní epistemologie. Jeho kritika ústí do formulace principu genetické paralely vyjádřeného tvrzením, že každá zásadnější kognitivní změna v mysli žáka probíhá způsobem, který je paralelní tomu, jak se tato změna uskutečnila v historickém kulturním vývoji instrumentální praxe. Souhlasíme s tím, že analýza a typologie kognitivních změn na úrovni historického vývoje kultury by měla být inspirací a oporou pro analýzu a zkoumání kognitivních změn na subjektivní úrovni.

Kriticky však konstatujeme, že Kvasz $(2016,2020)$ v citovaných textech nenabízí teoretické konstrukty pro výklad vztahů mezi epistemickými operacemi utvářejícími subjektivní zkušenost a sémanticko-logickými strukturami, které tuto zkušenost začleňují do sociálně sdíleného kontextu. Tato mezera brání operacionalizacím pro didaktický výzkum. Ve snaze ji zaplnit jsme chybějící konstrukty výše doplnili. $Z$ této výkladové pozice pak můžeme vysvětlovat re-kreaci žákovské zkušenosti aktivním obsahem jako proces kognitivních změn rozvrstvený do čtyř Kvaszem (2020) rozlišených typů: re-formulace, objektace, re-prezentace, idealizace. Zde k další diskusi nabízíme jejich stručnou didaktickou interpretaci opřenou o výše vyložené teoretické zázemí.

\subsection{Re-formulace}

Re-formulace je minimální kognitivní změna. Projevuje se zavedením nového termínu, který však podstatně nezasáhne do celkového pojetí systému, tedy nezpůsobuje funkční relační změny. Pro didaktiku je podstatné, že ve vzdělávací praxi se re-formulace snadno stává chabou náhražkou všech tři dalších typů kognitivních změn: učitel mưže být přesvědčen, že své žáky naučí myslet ve svém oboru jen postupnými re-formulacemi a tím brzdí nebo zamezuje dosažení komplexnějšího rozvoje. Kvasz (2020) v této souvislosti kritizuje, že metoda postupných re-formulací „nevytváŕí $v$ žákově mysli nové pojmy, ale odevzdává mu jenom přesné formulace hotových poznatků“. Z našeho pohledu jde o to, že nedochází k optimální replikaci memu, protože úlohy nejsou plnohodnotnými M-úlohami konstruovanými s ohledem na všechny čtyři typy kognitivních změn. 
Za didakticky nejcitlivější počáteční moment memetické replikace pokládáme objektaci (Kvasz, 2020). Objektací (zpředmětněním, reifikací) se rozumí „stabilizace kontaktu se skutečností “ prostřednictvím instrumentalizace vnímání (s. 9). ${ }^{24}$ Př́kladem je vznik pravidel lineární perspektivy $v$ renesančním maliřství, který vykládá Gombrich (1985) s oporou ve své teorii schémat. Ve vědě je objektace podmínkou k základnímu ontologickému rozlišování ,jednotek obsahu“ a podmínkou pro formulace proměnných (Slavík et al., 2017a, s. 54-60).

Na základě objektace vzniká a rozvíjí se schopnost „vyčlenit určitý kognitivní obsah, osamostatnit ho, udržovat ve vědomí a různě s ním manipulovat“ (Kvasz, 2020, s. 24). To lze $v$ transdidaktickém kontextu vyložit jako kognitivní penetraci obsahu představy prostřednictvím schématu, které fixuje daný způsob reprezentace obsahu a umožňuje zahájit jeho konceptualizace v konvencích jazykové formy (Slavík et al., 2013, s. 86-92). Díky jazykové reprezentaci dřive jen implicitní schéma explicitně vstupuje do intersubjektivního kulturního prostoru a může se $v$ něm obohacovat a uvědoměle replikovat jako strukturovaná obsahová jednotka - mem.

Provázáním představ $s$ jejich zaháčkováním $v$ jazyce zpravidla počíná učitelská práce. Na tomto základě jsou epistemicky kotveny všechny abstrakce a generalizace založené na výběrové syntéze separovaných momentů zkušenosti (Slavík et al., 2013, s. 73-77). $V$ tomto směru můžeme Kvaszovy matematické a fyzikální př́klady objektací rozšiřit třeba na strukturní vzorce v chemii, na hudební notaci, Labanưv systém taneční notace nebo na Linnéův objev taxonomie rostlinných a živočišných druhů. To jsou príklady klíčových kulturních schémat, která ukotvují objektaci a tím zároveň identifikují ten či onen obor a jeho díla (srov. Goodman, 1976/2007, s. 107-109).

\subsection{Re-prezentace}

Význačným kognitivním obohacením objektace je re-prezentace (Kvasz, 2020). Re-prezentace $v$ kulturní historii vede $k$ založení nového druhu instrumentální praxe a na ní závisející instrumentální zkušenosti. Je to tedy rozšiření, zpřesnění a zjemnění interakce se světem prostřednictvím objevu nového kontextu - nového zpưsobu goodmanovsky (1996) pojaté „světatvorby“ (worldmaking). Re-prezentace závisí na systematickém rozvíjení instrumentů v určitém oboru na „švu“ mezi smyslovými orgány, společným intencionálním jednáním a světem. Díky re-prezentacím se v instrumentální praxi vytvářejí a upevňují metody, metodologie a normativy, které umožňují vyhodnocovat rozdíly mezi správnou a méně správnými epistemickými modalitami provedení (srov. Janík \& Slavík, 2009, s. 122-123).

24 Instrumentalizace vnímání v uvedeném smyslu závisí na imaginaci ve spojení se sociálním učením, a to ve třech základních úrovních: 1) reprezentace obsahu - představit si a realizovat tentýž obsah a cíl jako předtím někdo jiný (imagining-for-learning), 2) plánování nebo inovace činnosti - představit si variabilní možnosti budoucího jednání, 3) porozumění jednání druhých bytostí - představit si, jak bych se rozhodoval na místě druhého, „v jeho kưži“, a odhadovat budoucí průběh jeho jednání (Currie \& Ravenscroft, 2011, s. 8-10). 
Kvasz (2020) zdůrazňuje, že kognitivní změny na úrovni re-prezentace ve vzdělávacím prostoru zůstávají neprozkoumané ve vztahu k utváření kulturní historické epistemologie. Tím uniká z okruhu didaktické pozornosti „kognitivní práce“, již musí žák vynaložit, aby skutečně porozuměl současné instrumentální praxi, tj. aby se k ní epistemicky propracoval od počátečního stavu uživání symbolů ve své dosavadní přirozené zkušenosti. Zřejmé je to v matematice. Nicméně také v ostatních oborech (s různou měrou náročnosti) vyžaduje vrůstání do způsobu myšlení oboru, tedy zvládnutí jednotlivých okruhů jeho memetické výbavy, speciálně připravovat $M$-úlohy, jejich kreativitu, množství, návaznost a postupnost ve spirálovém kurikulu, aby skutečně vystihovaly specifičnost oborových kognitivních procesů. Snad nejnázornější ilustraci lze nabídnout z oblasti hudební nebo tělesné výchovy: zvládnout „myšlení v oboru“ zde určitě neznamená jenom fixovat si určitý typ smyslových a pohybových představ, ale rozvinout je ve specifickém kulturním kontextu na základě nemalého úsilí do obrovského komplexu mentálních a pohybových dovedností, které rozlišují expertní instrumentalizaci od noviciátu. Didaktika je zavázána k výkladu tohoto procesu a k hodnocení jeho kvalit.

\subsection{Idealizace}

Nejradikálnější kognitivní změnou v uvedeném pojetí je idealizace. Idealizace spočívá ve „vytvoření nového jazyka, tedy nových pravidel jeho syntaxe a sémantiky, který umožňuje popisovat svět způsobem, který je ve shodě s výsledky instrumentální praxe“ (Kvasz, 2020, s. 10). Kvasz charakterizuje idealizaci prostřednictvím dvou jejích dílčích stránek: skladebné syntézy, deduktivní syntézy. Skladebná syntéza nastává tehdy, jestliže teorémy umožňují popisovat a vykládat systémy vzájemně interagujících částí, deduktivní syntéza je schopnost řadit fakty do deduktivních vztahů vzájemného vyplývání.

Domníváme se, že idealizace ve své čisté podobě s plně funkční a onticky závaznou skladebnou i deduktivní syntézou je vyhrazena pouze matematice a v těsné vazbě na ni též fyzice nebo dalším exaktním disciplínám přírodních věd. Přesto je zřejmé, že všechny ostatní obory se k nárokům idealizace do nějaké míry přibližují, mají-li se jejich memy v lidské kultuře replikovat. Důvodem je, že všechny obory musí být kulturně stabilizovány prostřednictvím sémanticko-logických struktur ve schématech své memetické výbavy, aby se mohly replikovat. Vypovídají o tom kupř. Wellmanem (1990) navržená kritéria pro hodnocení kvality jakékoliv konceptualizace: kritérium koherence a kritérium kauzálně explanatorního rámce. Kritérium koherence se týká kvality logické (inferenční) struktury konceptů, druhé kritérium vypovídá o explanační síle konceptualizačního jazyka. Obě kritéria zřejmě korespondují s nároky na idealizaci $\vee$ Kvaszově pojetí. Teprve na úrovni idealizace s uznávanou kulturní hodnotou prokazuje ta či ona instrumentální praxe dostatečnou kulturní váhu, aby vůbec přeživala v historickém vývoji a měla sílu stávat se součástí kurikula. 
Předložili jsme soustavu teoretických konstruktů pro výklad a výzkum působení aktivního obsahu ve vzdělávací praxi. Jejím koncepčním jádrem a zároveň diskusním předmětem je Kvaszova $(2016,2020)$ teze o typové shodě mezi kognitivními změnami v historické kulturní epistemologii a v osobní epistemologii. Kvasz (2016) tuto shodu vystihuje výše zmíněným principem genetické paralely. $V$ této stati jsme usilovali o další zdůvodnění a zároveň o funkční operacionalizaci pro didaktický výzkum výuky. Naše pozice je opačná, než je běžné v pedagogicko-psychologických př́stupech ke studiu kognitivních změn: vycházíme od výzkumu na úrovni historické kulturní epistemologie a směřujeme $k$ výzkumu na úrovni osobní epistemologie. Koncepčně se opíráme o předpoklad vzájemné závislosti tvorby a replikace memů při rozvíjení „kognitivních gestaltů“: schémat s jejich sémanticko-logickými strukturami.

Tvorba memů přináší inovace schémat v historické kulturní epistemologii. Historické inovace jsou ovšem produkovány lidmi - autory objevů. Ti první procházejí instrumentalizací zkušenosti tím, že v kritickém dialogu s druhými rozpracovávají ontologické základy svého oboru a jeho „způsob světatvorby“. Jak podotýká Kvasz (2001, s. 66), „Aristoteles [...] musel uskutečnit všechny objektace a re-prezentace, které jeho systém vyžaduje“. Proto kognitivní změny, jimiž je provázena tvorba memů během historického vývoje instrumentální praxe, jsou kognitivními změnami na úrovni osobní epistemologie objevitelů. Lze proto důvodně předpokládat, že analogickými změnami alespoň do jisté míry potřebují procházet i žáci při replikaci memů, má-li být replikace plnohodnotná, tj. má-li vést k optimální působnosti aktivního obsahu a k hlubokému osvojení instrumentální zkušenosti. Přitom platí, že univerzální meze poznání, tedy meze obsahu instrumentální zkušenosti jsou v dané historické době určeny aktuálním stavem kulturního vývoje instrumentální praxe $v$ daném oboru.

Máme za to, že Kvaszův princip genetické paralely má pro výzkum výuky a hodnocení její kvality závažné metodologické konsekvence s ohledem na výše zdůrazněné „vyprazdňování obsahu“ (tj. vytrácení psychodidaktiky) z pedagogicko-psychologických výzkumů. Čtyři druhy kognitivních změn (re-formulace, objektace, re-prezentace, idealizace) zjištěné Kvaszem při studiu historického kulturního vývoje matematiky a fyziky jsou význačné tím, že vyplývají z generalizace, která zachovává „kognitivní gestalt“ a instrumentální povahu zkušenosti v oboru. To znamená, že zachovává architekturu oborového obsahu: schémata a jejich sémanticko-logické struktury. Jinak řečeno, tento způsob generalizace dovoluje udržet v zorném poli oborově didaktické hledisko i při transdidakticky platné úrovni generalizace. Stojí za zdůraznění, že tuto ambici mají některé oborově didaktické výzkumy výuky ve světě i u nás (srov. Slavík et al., 2017a, s. 266-293). Proto může být účinným lékem proti „vyprazdňování obsahu“ z teorie nebo z metodologie empirických výzkumů výuky a hodnocení její kvality.

Domníváme se, že příčina „vyprazdňování obsahu“ se týká nejenom teoretického pojetí, ale je též metodologická: spočivá totiž ve způsobu vědeckého myšlení 
a vědeckého zkoumání. Výzkumy a teorie založené na „substančním“ pojetí statistické analýzy kategorizovaných dat nejsou s to „uvidět“ relační změny (Kvasz, 2016; Slavík et al., 2017a, s. 326-327; Rodová \& Slavík, 2018). Důvodem je metodologická absence zobrazování a analýzy kognitivních gestaltů - schémat prostřednictvím sémanticko-logických sítí. Tím uniká z pozornosti postupné utváření a rozvíjení sémanticko-logických struktur, které je společným základem jak pro tvorbu memů, tak pro jejich replikování s oporou $\mathrm{v}$ jazykových konceptualizacích. Je tedy oporou pro vysvětlování paralel mezi rozvojem instrumentální zkušenosti v historické kulturní epistemologii a osobní epistemologii.

$V$ této stati jsme navrhli soustavu teoretických konstruktů opřených o termíny sémanticko-logická struktura - schéma - mem, které mají být východiskem pro alternativní metodologii empirického zkoumání vzdělávací praxe. Její výchozí nástiny pod názvem metodika $3 A$ byly publikovány v monografiích Janíka et al. (2013) a Slavíka et al. (2017a) či v navazujících statích a jsou otevřeny k dalšímu promýšlení a rozpracování.

\section{Dedikace}

Stat' byla zpracována v rámci řešení projektu GAČR 20-13038S, Produktivní kultura vyučování a učení.

\section{Literatura}

Anderson, L. W., \& Krathwohl, D. R. (Eds.). (2001). A taxonomy for learning, teaching, and assessing: A revision of Bloom's taxonomy of educational objectives. Longman.

Anderson, R. C., \& Pearson, P. D. (1984). A schema-theoretic view of basic processes in reading comprehension. In P. D. Pearson (Ed.), Handbook of reading research (s. 255-291). Longman.

Aristotelés (cca 350 př. n. l./2008). Metafyzika. Petr Rezek.

Barbaras, R. (2005). Touha a odstup. OIKOYMENH.

Bloomfield, L. (1946). Linguistic aspects of science. In O. Neurath, R. Carnap, \& C. W. Morris, International encyclopaedia of unified science. 1. díl. University of Chicago Press.

Brentano, F. (1973). Psychology from an empirical standpoint. Routledge \& Kegan Paul. Původně publikováno 1874 .

Britannica. (2017). Supervenience. https://www.britannica.com/topic/supervenience

Currie, G. \& \& Ravenscroft, I. (2011). Recreative minds: Imagination in philosophy and psychology. Oxford University Press.

Čapek, J. (2012). Maurice Merleau-Ponty: Myslet podle vnímání. Filosofia.

Dawkins, R. (1989). The selfish gene. Oxford University Press.

Dennett, D. (1991). Consciousness explained. Back Bay Books.

Dennett, D. (2004). Druhy myslí. Academia.

Dewey, J. (1938). Experience and education. Touchstone.

Fisherman, D. (2012). Mind, education, and active content. In C. W. Ruitenberg (Ed.), Philosophy of education (s. 163-171). Philosophy and Education Society.

Gombrich, E. H. (1985). Umění a iluze. Odeon.

Goodman, N. (1996). Způsoby světatvorby. Archa. 
34 Goodman, N. (2007). Jazyky umění. Academia. (Původně publikováno 1976.)

Goodman, N., \& Elginová, C. Z. (2017). Nové pojetí filozofie a dalších umění a věd. Univerzita Karlova - Filozofická fakulta.

Greiffenhagen, C., \& Sherman, W. (2006). Kuhn and conceptual change: On the analogy between conceptual changes in science and children. Science \& Education, 17(1), 1-26.

Hawthorne, J. (2007). Understanding creativity through memes and schemata. University of New South Wales.

Hejný, M. (2008). Scheme-oriented educational strategy in mathematics. In B. Maj, M. Pytlak, \& E. Swoboda (Eds.), Supporting independent thinking through mathematical education. Proceedings of CME 08 Conference (s. 40-48). Nawa Era.

Hejný, M., \& Kuřina, F. (2000). Tři světy Karla Poppera a vzdělávací proces. Pedagogika, 50(1), 38-50.

Hofstadter, D. R. (2012). Gödel, Escher, Bach. Existenciální gordická balada. Metaforická fuga o mysli a strojích v duchu Lewise Carolla. Argo, Dokořán.

Husserl, E. (1993). Karteziánské meditace. Svoboda-Libertas.

Chocholoušková, Z., \& Hajerová Müllerová, L. (2020). Vliv terénní exkurze na modifikaci žákovských prekonceptů odborných pojmů. Scientia in Educatione, 11(1), 22-42.

Chrz, V., Nohavová, A., Slavík, J. (2015). Psychologická gramotnost ze dvou poznávacích perspektiv: Aktuální výzva pro výuku psychologie a její didaktiku. Studia paedagogica, 20(3), 21-46.

Jacob, P. (2019). Intentionality. In E. N. Zalta (Ed.), The Stanford encyclopedia of philosophy. https://plato.stanford.edu/archives/win2019/entries/intentionality/.

Jan, S. (2000). Replicating sonorities: Towards a memetics of music. Journal of Memetics Evolutionary Models of Information Transmission, 4(1), 1-51.

Janík, T., \& Slavík, J. (2009). Obsah, subjekt a intersubjektivita v oborových didaktikách. Pedagogika, 59(2), 116-135.

Janík, T., Slavík, J., Mužík, V., Trna, J., Janko, T., Lokajíčková, V., Lukavský, J., Minaříková, E., Sliacky, J., Šalamounová, Z., Šebestová, S., Vondrová, N., \& Zlatníček, P. (2013). Kvalita (ve) vzdělávání: Obsahově zaměřený přistup ke zkoumání a zlepšování výuky. Masarykova univerzita.

Janík, T., Slavík, J., Najvar, P., \& Janíková, M. (2018). Shedding the content: Semantics of teaching burdened by didactic formalisms. Journal of Curriculum Studies, 51(2), 185-201.

Janík, T., Slavík, J., Najvar, P. \& Jirotková, D. (2020). The same and the different: On semantization and instrumentalization practices in the (maths) classroom. SAGE Open, 10(3), 1-12.

Juklová, K. (2019). Osobní epistemologie budoucího učitele. Predikce a podpora studijních procesů a výsledků. Grada.

Kohout, J., Mollerová, M., Masopust, P., Feřt, L., \& Slavík, J. (2019). Kritická místa kurikula na základní škole pohledem mezinárodního šetření TIMSS a českých učitelů - poznatky z fyziky. Pedagogická orientace, 29(1), 5-42.

Kolb, D. A. (1984). Experiential learning. Prentice-Hall.

Kozbelt, A. (2008). E. H. Gombrich on creativity: A cognitive-historical case study. Creativity Research Journal, 20(1), 93-104.

Kuhn, T. S. (1997). Struktura vědeckých revolucí. OIKOYMENH.

Kvasz, L. (2001). O Piagetovi, dialektike a členskom. Organon, 8(1), 56-73.

Kvasz, L. (2008). Patterns of change: Linguistic innovations in the development of classical mathematics. Birkhäuser.

Kvasz, L. (2015). Inštrumentálny realizmus. Západočeská univerzita v Plzni, Pavel Mervart.

Kvasz, L. (2016). Princípy genetického konštruktivizmu. Orbis scholae, 10(2), 15-45.

Kvasz, L. (2020). Inštrumentálny realizmus ako možné východisko teoretickej reflexie vyučovania matematiky. Orbis scholae, 14(1), 7-32.

Lee, J. (1920). Play in education. Macmillan.

Mason, L. (2007). Bridging on cognitive and sociocultural approaches in research on conceptual change: It is feasible? Educational Psychologist, 42(1), 1-7.

Materna, P. (1995). Svět pojmů a logika. Filosofia. 
Nohavová, A. (2018). Didaktika psychologie: Od cíle výuky k jeho realizaci. Jihočeská univerzita - Pedagogická fakulta.

Peregrin, J. (1999). Význam a struktura. OIKOYMENH.

Piaget, J. (1983). Piaget's theory. In P. Mussen (Ed.), Handbook of child psychology. Wiley.

Plassová, M., Stuchlíková, I., \& Vařečka, M. (2017). Úvod do aproximálního numerického systému. Pedagogika, 67(2), 161-176.

Popper, K. R. (1998). Život je řešení problémů. Mladá fronta.

Pražák, J. M., Novotný, F., \& Sedláček, J. (1948). Latinsko-český slovník. Grafická unie.

Rámcový vzdělávací program pro gymnázia. (2007). Výzkumný ústav pedagogický.

Rámcový vzdělávací program pro základní vzdělávání. (2005). Výzkumný ústav pedagogický.

Rodová, V., \& Slavík, J. (2018). Živé obrazy jako metoda výuky dějepisu: Analytické zobecnění poznatků z praxe. Studia paedagogica, 23(3), 9-48.

Searle, J. R. (2004). Mind: A brief introduction. Oxford University Press.

Schütz, A. (1953). Common-sense and scientific interpretation of human action. Philosophy and Phenomenological Research, 14(1), 1-38.

Slavík, J. (2017). Kvaszův instrumentální realizmus v zorném poli didaktiky. Pedagogika, 67(3), 311-322.

Slavík, J., Chrz, V., \& Štech, S. (Eds.). (2013). Tvorba jako způsob poznávání. Karolinum.

Slavík, J., \& Janík, T. (2005). Významová struktura faktu v oborových didaktikách. Pedagogika, 55(4), 336-353.

Slavík, J., \& Janík, T. (2006). Teorie, výzkum a tvorba školy. Pedagogika, 56(2), 168-177.

Slavík, J., \& Janík, T. (2012). Kvalita výuky: Obsahově zaměřený př́istup ke studiu procesů vyučování a učení. Pedagogika, 62(3), 262-286.

Slavík, J., Janík, T., Najvar, P., \& Knecht, P. (2017a). Transdisciplinární didaktika - o učitelském sdílení znalostí a zvyšování kvality výuky napřič obory. Masarykova univerzita.

Slavík, J., Stará, J., Uličná, K., Najvar, P. (Eds). (2017b). Didaktické kazuistiky v oborech školního vzdělávání. Munipress.

Strawson, P. F. (1997). Individuá. Esej o deskriptívnej metafyzike. Iris.

Šíp, R. (2016). Filozofická východiska výzkumu tacitní znalosti: Znalost, figurativní jazyk a metafora. In V. Švec, J. Lawley, J. Nehyba, P. Svojanovský, R. Šíp, E. Minaříková, B. Pravdová, B. Šimůnková \& J. Slavík, Studenti učitelství mezi tacitními a explicitními znalostmi (s. 21-82). Masarykova univerzita.

Štech, S. (2013). Kognitivní vývoj mezi reprodukcí a inovací. In J. Slavík, V. Chrz, \& S. Štech (Eds.), Tvorba jako způsob poznávání (s. 29-44). Karolinum.

Štěpáník, S., \& Slavík, J. (2017). Žákovské prekoncepty jako konstitutivní prvek výuky českého jazyka. Pedagogická orientace, 27(1), 58-80.

Vygotskij, L. S. (1976). Myšlení a řeč. Státní pedagogické nakladatelství.

Wellman, H. (1990). The child's theory of mind. MIT Press.

doc. PaedDr. Jan Slavík, CSc. katedra pedagogiky

Fakulta pedagogická

Západočeská univerzita v Plzni

Veleslavínova 42, 30100 Plzeň slavikj@kvk.zcu.cz

prof. PhDr. Mgr. Tomáš Janík, Ph.D. Institut výzkumu školního vzdělávání

Pedagogická fakulta Masarykova univerzita Pořičí 7/9, 60300 Brno tjanik@ped.muni.cz 
doc. Mgr. Jiří Kohout, Ph.D. katedra matematiky, fyziky a technické výchovy

Fakulta pedagogická Západočeská univerzita v Plzni

Klatovská tř. 51 30614 Plzeň

jkohout4@kmt.zcu.cz

Mgr. Tereza Češková, Ph.D. Institut výzkumu školního vzdělávání a katedra geografie

Pedagogická fakulta, Masarykova univerzita Poŕíćí 7/9, 60300 Brno ceskova@ped.muni.cz

doc. RNDr. Pavel Mentlík, Ph.D. Centrum biologie, geověd a envigogiky

Fakulta pedagogická Západočeská univerzita v Plzni, Klatovská tř. 51 30614 Plzeň pment@cbg.zcu.cz

doc. Mgr. Petr Najvar, Ph.D. Institut výzkumu školního vzdělávání a katedra primární pedagogiky Pedagogická fakulta, Masarykova univerzita Poŕící 7/9, 60300 Brno najvar@ped.muni.cz 